\title{
Nalewka srebrna z miednicą — atrybut elitarnej kultury stołu we wczesnonowożytnej Europie Środkowej. Uwagi wstępne
}

\author{
Słowa kluczowe: nalewka, uczta, luksus, szlachta, Europa Środkowa, nowożytność \\ Key words: handwashing jug, feast, luxury, nobility, Central Europe, \\ early modern period
}

W przypisywanym Tannhäuserowi, trzynastowiecznym poemacie Hofzucht (Dworność) znajdujemy ostrzeżenie: ,jeśli to prawda, zła to wieść/co słyszeć o niejednym muszę/ że rąk nie myjąc siada jeść/ straszyć by takich paraluszem”. W wieku XIV francuski poeta pisał: „Dziecię szlachetne, umyj ręce/ gdy wstaniesz i zanim obiad zjesz/ i niezawodnie przed wieczerzą/ Trzy razy najmniej tak masz czynić"2. Mycie rąk przed posiłkiem było stałym elementem zachowania zgodnego ze średniowiecznym savoir-vivre. Również ludzie doby nowożytnej, zwłaszcza cywilizowani - kulturalni musieli spełniać ten wymóg. Granice przyzwoitości były jednak szerokie. Na jednym biegunie można umieścić doświadczenie Erazma z Rotterdamu. W dialogu Domy zajezdne (wyd. Bazylea 1523) opisuje znane sobie z autopsji gospody niemieckie i francuskie. Przebywający we wspólnej izbie goście — blisko sto osób, z różnych stanów (od ubogich i prostaków do zamożnych i szlachty) - mogą umyć ręce. Miska jest jednak tak brudna, ,że potrzeba drugiej, aby spłukać z siebie tę wodę"; brudne są także talerze, marne wino. Na reklamacje oberżysta odpowiada: „Gościłem niemało szlachty i hrabiów. Jeśli tu waszmości nie odpowiada, niech sobie poszuka innej kwatery"3; to niski poziom kultury, choć zapewne nie najniższy. Z kolei w wydanym w roku 1530 De civilitate morum puerilium ten sam Erazm formułuje rady dla elity, dla przyszłych książąt. Ponieważ wszyscy — od chłopa do króla - biorą jedzenie palcami, przed posiłkiem należy umyć ręce. Filozof potwierdza obyczaj utrwalony w średniowiecza, znany już w starożytności.

W dobie nowożytnej mycie rąk poprzedzało uczty na dworach europejskich panujących. Przynajmniej przy pierwszych, najwyższych stołach związane było z pewnym ceremoniałem. Według znawcy ceremoniału dworskiego z przełomu XVII i XVIII w. Juliusa Bernharda von Rohr, np. na dworze hiszpańskim podczaszy, trzymając w prawej ręce nalewkę (dzban — Giesskanne), w lewej zaś miednicę (Giess-becken), przyklękając podawał królowi wodę do mycia. Po dokonaniu ablucji władca wysuszał dłonie serwetą podaną przez innego dworzanina ${ }^{4}$. Podobny obyczaj obowiązywał na dworze francuskim. Na przykład w roku 1571 mycie rąk poprzedziło ucztę z okazji wjazdu do Paryża Karola IX i jego żony Elżbiety Austriaczki ${ }^{5}$.

\footnotetext{
1 Cyt. za: Elias N. 2011, s. 135.

2 Cyt. za: tamże, s. 156.

3 Cyt za: tamże, s. 142.

4 Rohr J.B. 1733, s. 124.

5 Rottermund A. 1987, s. 54.
} 
Obmycie dłoni było też stałym elementem biesiad królewskich w Polsce. Na piętnastowiecznym dworze Jagiellonów monarcha rozpoczynał ucztę, ,zwyczajowo obmywając ręce"6. Podobnie było za Wazów. Za Zygmunta III, w latach dziewięćdziesiątych XVI w., królowi i osobom towarzyszącym mu przy stole podawano bogato zdobione ręczniki, miednice i dzbanki (w 1596 r. np. z kryształu). W czasie jednej z uczt w roku 1633, jedna miednica służyła tylko Władysławowi IV, dwie pozostałe osobom zasiadającym odpowiednio po jego prawicy i lewicy. Biesiadujący przy niższych stołach myli ręce na stojąco, nie zaś przy stole ${ }^{7}$. Podobną ceremonię, poprzedzającą ucztę elity (królewską, magnacką) zrekonstruował na progu XX w. Władysław Łoziński; pisał on: „Przed rozpoczęciem uczty przystępowało do każdego gościa po kolei czterech rękodajnych dworzan gospodarza, a mianowicie najpierw dwaj, z których jeden niósł nalewkę srebrną z wodą, drugi zaś miednicę srebrną wielkich rozmiarów; jeden nalewał wodę na ręce, drugi podtrzymywał miednicę. Dwaj dalsi trzymali za końce ręcznik długości kilku łokci, którym goście obcierali dłonie"8.

$\mathrm{Z}$ czasem wiedzy na ten temat raczej nie przybywało. W późniejszej o z górą półwieku Historii Kultury Materialnej Polski w zarysie znajdujemy tylko lakoniczną, dość mylącą wzmiankę: „Przed ucztą myto ręce w srebrnych nalewkach”9. Takie stwierdzenie wynika zapewne z nieprecyzyjnego zdefiniowania owej nalewki. W literaturze przedmiotu bywała uznawana za synonim „lawaterza, umywadlnika, handfasu, umyvadla” określanych ogólnie jako „naczynie do mycia”, ewentualnie jako „naczynie służące do lania wody przy myciu rąk, może też miska, umywalka" ${ }^{10}$. Tymczasem dość jasne rozróżnienie niemieckiego Handfaß i polskiego konwas-antwas od nalewki znajdujemy choćby w gdańskich dialogach Volckmara z końca XVI w. Przed biesiadą w zamożnym domu mieszczańskim służący otrzymuje polecenie ,,przynieś wodę w konwas, abo [podkreślenie - A.K.] nalej w nalewkę a miednicę"11. Według encyklopedii dla kobiet Frauenzimmer-Lexicon Corvinusa z 1739 r., nalewka (Giesskanne) stanowi komplet z miednicą — misą (Giessbecken). Ta druga, wykonana ze srebra, porcelany lub cyny, ma kształt owalny lub okrągły, na niej jest ustawiana nalewka. Ta ostatnia, wykonywana $z$ tych samych materiałów co misa, ma formę dzbanka $\mathrm{z}$ uchem ${ }^{12}$.

Prosta a zarazem jasna jest definicja Kopalińskiego: nalewka — „dawniej mała konewka do polewania rąk przy myciu przed jedzeniem i po jedzeniu (były też niekiedy kosztowne, z kryształu górskiego, srebra, artystycznie wykonane)"13. Z kolei według Słownika staropolskiego nalewka to „naczynie metalowe do nalewania płynów, najczęściej służące do polewania rąk"14. Ostatnio Dariusz Główka precyzyjnie zdefiniował handfass, w odróżnieniu od nalewki, jako ,zbiornik na wodę z kurkiem i miednicą umieszczony w szafce"15.

Skutki niejasności terminologicznych widać też w interpretacji ikonografii. Między innymi na rycinach w Historii Kultury Materialnej Polski nalewka nie jest identyfikowana właściwie. W podpisie pod rycinami ukazującymi nalewkę z misą czytamy: srebrny dzban (wys. 25,5 cm) i ,należąca do niego misa” (Augsburg 1617), bez wskazania wspólnej funkcji obu naczyń ${ }^{16}$.

${ }^{6}$ Wasilewicz M. 2016, s. 132.

7 Taźbierski Z. 1986, s. 99; Leitsch W. 2009, s. 990, 2169-2170.

${ }^{8}$ Łoziński W. 2006, s. 215.

${ }^{9}$ Historia. 1978, s. 321.

${ }^{10}$ Słownik polszczyzny. 1979, XIV, s. 67, 294.

${ }^{11}$ Volckmar N. 2005, s. 91.

${ }^{12}$ Corvinus 1739, s. 578.

${ }_{13}$ Kopaliński W. 1985, s. 727.

${ }^{14}$ Słownik staropolski 1965, s. 57.

${ }^{15}$ Główka D. 2004, s. 179-180.

${ }^{16}$ Historia 1978, s. 286-288, ryc. 132-133. 
Używanie nalewek na dworach europejskich władców potwierdzają różne źródła: zabytki muzealne zachowane w skarbcach (a przynajmniej odnotowane w dawnych ich rejestrach), dokumentacja zakupów, darów, łupów, inwentarze majątkowe, testamenty, wreszcie źródła narracyjne: korespondencja, dzienniki, relacje z podróży — materiał źródłowy liczny, zróżnicowany i ogromnie rozproszony.

Zachowały się nalewki używane na dworze Habsburgów austriackich. Z końca XVI w. pochodziła wykonana przez mistrza norymberskiego Krenbergera, zdobiąca praską rezydencję Rudolfa II, misa ze srebra w większej części złoconego z należącą do niej nalewką, zdobiona drogimi kamieniami, muszlami pereł i perłami; w końcu trafiła do zbiorów wiedeńskiego Hofburga $^{17}$. Na inny zestaw, pochodzący z początku XVII w. i także przechowywany w wiedeńskim skarbcu, składały się złocona misa (z przedstawieniem w centrum triumfu Amora, z trybowanymi scenami z dzieł Owidiusza na obrzeżach) oraz nalewka zdobiona trybowaniem i emalią ${ }^{18}$.

Tego typu naczyń nie brakowało też na dworze Wazów. W spisie skarbca prywatnego Zygmunta III z 1632 r. wśród „służby szczerozłotej” (nakryć stołowych) odnotowano „miednic złotych dwie z nalewkami"'19. Na dwór królewski nalewki trafiały różną drogą, m.in. jako dary. Gdy w roku 1594 Zygmunt zatrzymał się w Poznaniu, od Rady Miejskiej otrzymał nalewkę srebrną z miednicą. W 1605 r. wśród podarunków weselnych dla królowej Konstancji (druga żona Zygmunta) znalazła się zakupiona przez żołnierzy ,złota misa z małym złotym dzbankiem [nalewka ? - A.K] z herbami moskiewskimi" ${ }^{20}$. Nalewka bywała także podarunkiem dyplomatycznym. W 1611 r. taż Konstancja otrzymała od posła elektora brandenburskiego naleweczkę z miedniczką z bursztynu ${ }^{21}$. Podobnym zestawem obdarzył królową hospodar mołdawski ${ }^{22}$. W roku 1638 elektor bawarski Maximilian zamówił w Augsburgu złotą miedniczkę z naleweczką (ain guldin handbekhin vnd gueßkanten) oraz z kilkoma misami i talerzami. Były one przeznaczone dla jego siostrzenicy Cecylii Renaty, od 1637 r. małżonki Władysława IV Wazy ${ }^{23}$.

Drogą dyplomatyczną nalewki docierały także na dwór carów rosyjskich. W katalogu wystawy Skarby Kremla. Dary Rzeczypospolitej Obojga Narodów, oprócz innych kosztownych wyrobów rzemiosła artystycznego zaprezentowano pięć kompletów nalewek z misami. Dzieła rzemieślników z Antwerpii, Augsburga i Gdańska poselstwa polskie przekazały w drugiej połowie XVII w. jako podarki osobiste króla, prezenty od Rzeczypospolitej lub poszczególnych uczestników poselstwa. Dary te były eksponowane w sali audiencyjnej Kremla, podczas paradnych uczt. Na jednym lub kilku bufetach umieszczano puchary, tace, figurki zwierząt oraz właśnie komplety naczyń do mycia rąk $\mathrm{k}^{24}$.

${ }^{17}$ Prünkschüssel mit zugehörige Kanne, Knackfuß H. 1888, s. 89, Abb. 508-509.

${ }_{18}$ Knackfuß H. 1888, s. 96, Abb. 515-516.

19 Testamenty Zygmunta III. 2013, s.21.

20 Testamenty Zygmunta III. 2013, s.106.

21 Leitsch W. 2009, s. 2170.

22 W roku 1606, Leitsch W. 2009, s. 2170.

${ }^{23}$ List Filipa Hainhofera do Augusta Młodszego księcia Brunszwiku-Lüneburga, Augsburg 12 września 1638, Der Briefwechsel. 1984, s. 652.

${ }^{24}$ Listę otwiera: 1) nalewka z Augsburga (1635-1640), dar Władysława IV dla Aleksego Michajłowicza (1647), srebro złocone, repusowane, grawerowane, wcześniej własność Krzysztofa Radziwiłła wojewody wileńskiego. Do kompletu misa, w centrum repusowana scena bitewna; 2) nalewka z Antwerpii (1544-1546). Dzban muszla Nautilus, srebro, złoto, diamenty, rubiny, szmaragdy, perły. Dar Jana Kazimierza dla Aleksego Michajłowicza (1651). Do kompletu misa - miednica z Norymbergi (połowa XVI w.), srebro, macica perłowa, diamenty, rubiny; 3 ) nalewka z misą z Gdańska (1630-1650), srebro repusowane, złocone. Forma dużo prostsza niż w przypadku nalewek z Niemiec oraz Niderlandów. Dar Jana Kazimierza dla Aleksego Michajłowicza (1667); 4) nalewka z misą, Augsburg (ok. 1650 r.), srebro złocone. Dar posła Cypriana Brzostowskiego dla Aleksego Michajłowicza; w lustrze misy scena spotkania Diogenesa z Aleksandrem Macedońskim; 5) nalewka w kształcie jeźdźca, Augsburg (1680-1684), srebro złocone, repusowane. Dar Jana III Sobieskiego(?) z 1686 r. dla Iwana 
Wydaje się, że kilka nalewek zachowanych spośród darów trafiających z Polski na dwór carów w ciągu czterdziestolecia 1647-1686 to niezbyt wiele. Źródła pisane potwierdzają jednak dużą ich popularność jako prezentu od przedstawicieli Rzeczypospolitej. Uczestnicy jednego tylko poselstwa z 1667 r., na którego czele stał Eustachy Tyszkiewicz wojewoda czernichowski, podarowali Rosjanom kilka nalewek. Od króla Jana Kazimierza „miednicę wielką z nalewką pozłocistą”, od wojewody — posła wielkiego, kolejną, srebrną pozłacaną. Darczyńcami byli nawet dworzanie pokojowi JKM. Ci ostatni przekazali tylko nalewki z miednicami; wyżsi rangą członkowie poselstwa oprócz nalewek także inne prezenty ${ }^{25}$.

Posiadaczami luksusowych nalewek byli nie tylko najwięksi monarchowie. Wraz z miednicami były używane również na dworach elektorów i pomniejszych panujących w Rzeszy. Ich osobiste zainteresowanie tymi przedmiotami potwierdza korespondencja Filipa Hainhofera (1578-1647), wywodzącego się z uszlachconej patrycjuszowskiej rodziny z Augsburga marszanda, kolekcjonera, agenta a zarazem przyjaciela i korespondenta wielu władców. Wzmianki o nalewkach znajdujemy, w różnym zresztą kontekście, w wydanej korespondencji Filipa z księciem Augustem Młodszym z linii brunszwicko-lüneburskiej z lat 1613-1647. Dotyczą zarówno zakupów dla samego Augusta (planowanych i zrealizowanych), jak też augsburgskich zakupów innych władców. W liście do Filipa Hainhofera z 13 września 1614 r., książę przypominał o nalewkach (Giesskanten) i miednicach (Giessbekken), których dostarczenia żądał przed ośmiu dniami. Miały być całe złocone (gantz verguldet) ${ }^{26}$. Agent odpowiedział, że zgodnie z życzeniem mocodawcy, oprócz innych sreber zakupił od jednego $\mathrm{z}$ augsburgskich złotników miednicę z nalewką wartą 16,5 florena; pokreślił, że jest wykonana według najnowszej mody i pięknie zdobiona płaskorzeźbą $^{27}$. Z lat 1639 i 1647 pochodzą faktury poświadczające wysyłkę z Augsburga do Brunszwiku nalewek określanych jako z Limusin albo francuskie ${ }^{28}$. Z kolei sam Hainhofer, pisząc do Augusta (5 stycznia 1623 r.) wspomniał o zamówieniu w Augsburgu przez księcia Maksymiliana Bawarskiego dwóch złotych miednic do mycia rąk; każda ważyła 100 grzywien ${ }^{29}$. W lipcu roku 1638 donosił księciu o zakupie pięciu srebrnych miednic (o wadze 64-70 grzywien) dla jednego $\mathrm{z}$ wodzów cesarskich ${ }^{30}$. Zdobiły je przedstawienia czynów Aleksandra Wielkiego i Bucefała. Zamówienie obejmowało także hebanowe stoły do pisania i dwa blaty stołowe inkrustowane srebrem. Jego ogólną wartość Hainhofer szacował na kilka tysięcy talarów. Być może tego typu doniesienia miały skłonić Augusta Młodszego do intensywniejszych zakupów.

Władcy w Rzeszy chętnie demonstrowali posiadanie, obok innych sreber, luksusowych miednic i nalewek. Wspominany powyżej Hainhofer w relacji z pobytu na dworze Filipa II księcia Pomorza Szczecińskiego (sierpień-październik 1617 r.) informuje o zdobiącym jadalnię zamku w Szczecinie kredensie, w którym eksponowano dużą liczbę (Haufen) pięknych naczyń srebrnych. Była wśród nich miednica duża, niegdyś podarowana przez cesarza Rudolfa posłowi

i Piotra Aleksejewiczów. Towarzyszy jej misa z tego samego materiału. Kompozycja lustra „Pokonani Partowie przed Tyberiuszem" w niektórych elementach nawiązuje do austriacko-polskiej wiktorii wiedeńskiej; Skarby. 1998, nr 21-24, 25-27, 32-33, 35-36.

25 Niemcewicz J.U. 1840, s. 462-463: „Od króla — «kareta z cugiem koni», od wojewody — «zegar misterny bijący i śpiewający, dwie flasze srebrne pozłacane»".

${ }^{26}$ Der Briefwechsel. 1984, nr 91.

27 Tamże, nr 93 (list do księcia z 25 września 1614 r.): noch ain schones handbeckn vnd gueß Canten von ainem goldtschmidt [...] wellches wigt 16 m.9.l zu fl 16 1/2 die weil es hüpsch punzioniert, vnd aine ganz newe invention ist.

${ }^{28}$ Wśród obrazów, ksiąg, naczyń znalazły się: piękna szmelcowana miednica i nalewka w czystym futerale — ain schon geschmelztes limosiner handbekhin vnd gueß Canten in sauberen fueteral (Der Briefwechsel. 1984, nr 1264, s. 658, 660); francuska nalewka została wysłana do Brunszwiku, zgodnie z fakturą z 29 marca 1647 r.: In ainem saubern fueteral, 1 schon franzosisch handbeckhin vnd gueßkhanten (tamże, nr 1492, s. 809).

${ }^{29}$ Der Briefwechsel 1984, nr 661.

${ }^{30}$ Tamże, nr 1234: 5 grose silberne handbek hiner von 64 biss in 70 markh iedes schwer. 
moskiewskiemu, później sprzedana do Szczecina (mamy tu do czynienia z wtórnym obiegiem darów dyplomatycznych ?). Sam Hainhofer, jako gość księcia, miał codziennie do własnej wyłącznej dyspozycji „ładną, dużą, srebrną miednicę do mycia rąk”31. W wydanym w roku 1683 „Krótkim opisaniu [...] najpiękniejszych [...] kunsztownych przedmiotów i innych nieocenionych dzieł" znajdujących się w Dreźnie, stolicy Saksonii, wśród setek eksponowanych we wnętrzach rezydencji Wettynów przedmiotów, autor dziełka Tobiasz Beutelius, elektorski sekretarz, wymienił prezentowane w osobnej sali wraz rzeźbami i automatami „miedniczkę i naczynie do mycia rąk [nalewkę? - A.K.] z bladożółtego bursztynu w oprawie złotej ${ }^{32}$.

Od roku 1703 po II wojnę światową salę rycerską zamku w Berlinie zdobił Srebrny Bufet (Silberbufett). Eksponowano w nim kilkanaście wykonanych z pozłacanego srebra wanien do mycia naczyń (Spulwanne) oraz przeznaczonych jedynie do tego typu dekoracji pękatych szklanych flasz w złoconych oprawach (Kettenflasche). Zestaw uświetniało 9 kompletów nalewek z miednicami (Giessgarnituren). Jeden z nich został zamówiony w Augsburgu w roku 1695 przez elektora Fryderyka III, wykonany zaś w trzy lata później przez tamtejszych złotników Johanna Ludwiga i Albrechta Billera ${ }^{33}$.

Posiadanie nalewek przez Hohenzollernów potwierdzają także testamenty elektorów. W ostatniej woli wielkiego elektora Fryderyka Wilhelma (1651 r.), wśród precjozów zapisanych żonie Luizie, obok biżuterii oraz sreber stołowych znalazły się nalewki z miednicami ${ }^{34}$. Fryderyk III w testamencie z roku 1692 zapisał żonie wśród innych kosztowności miedniczkę z nalewką. Ta ostatnia nie pełniła roli srebra stołowego, stanowiąc część złotego zestawu toaletowego złożonego jeszcze z lustra oraz puderniczek, flaszek i kubków ${ }^{35}$.

Za przykładem władców podążała elita szlachty. Nalewka była ważną częścią zastawy arystokracji w Czechach. Z lat dwudziestych XVI wieku pochodzi informacja o darze kanclerza królestwa Czech Ladislava ze Stermberka dla żony Anny z Hradca. Wśród licznych sreber otrzymała pozłacane — miednicę z nalewką ${ }^{36}$. Również Albrecht Johan Smiřicki (1594-1618), ostatni męski przedstawiciel najbogatszego w dobra ziemskie rodu Czech północnych ${ }^{37}, \mathrm{w}$ swym praskim pałacu posiadał według inwentarza z roku $1611 \mathrm{~m}$.in. srebrne ,umyvadlo z nálevkou”. W 1618 r. z tejże rezydencji wywieziono do Frankfurtu n. M. wszelkie cenne ruchomości, w tym srebra i biżuterię. Po bitwie pod Białą Górą cesarz wymusił zwrot tego majątku. Podlegał on konfiskacie na rzecz skarbu jako własność czołowego buntownika. Przejęto m.in. 108 złoconych naczyń do picia z nakrywkami i bez nich, 156 dużych i małych mis, 73 czary, 84 talerze, 22 solniczki, 24 lichtarze, 12 flasz, wreszcie 5 miednic z przynależnymi nalewkami ${ }^{38}$. Jedni tracili dobra, inni je zyskiwali. Czołowy wódz wojsk cesarskich Albert Wallenstein zgromadził w swoim praskim pałacu (wg inwentarza z 1634 r.) wśród innych sreber: 37 miednic i 31 nalewek (w tym 17 złoconych); do tego miednicę z dwiema naleweczkami ${ }^{39}$.

31 Hainhofer. 1834, s. 111-112: ein hüpsch groß silberin handbeckin.

${ }^{32}$ Kossowicz J.M. 2017, s. 198, 180: malluvium et gutturnium ex succino flavo et candido.

33 Kunstgewerbemuseum. 1983, s. 59.

34 Die Testamente. 1915, s. 167: Gieskannen und Becken.

35 Tamże, s. 310.

36 Bůžek V., Hrdlička J. 1998, s. 170.

37 Albrecht Johann był panem jednej z największych domen w Europie Środkowej (1/4 Czech). Członek Stanu Pańskiego, absolwent kalwińskiego uniwersytetu w Heidelbergu, miał za sobą podróże do Francji, Anglii, Włoch. Był narzeczonym księżniczki Amelii Elżbiety von Hanau; przypisywano mu ambicje królewskie. W 1618 r. dokonał błędnego wyboru politycznego. Został jednym z 30 dyrektorów powstania czeskiego. Bardzo zaangażowany w sprawę ,zimowego króla” Fryderyka z Palatynatu, własnym kosztem wystawił 1200 pieszych i 90 jeźdźców. Po krótkiej chorobie zmarł w Pradze, w listopadzie 1618 r., Lemberg M. 1994, s. 10-18.

38 Dějiny. 1995, s. 267.

39 Bilek T. 1882, s. 827. 
Nalewek nie brakowało też na dworach magnatów z Rzeczypospolitej. Posiadaczką wielu była Ludwika Karolina Radziwiłłówna, późniejsza (od 1681 r.) żona Ludwika Hohenzollerna, margrabiego brandenburskiego, trzeciego syna Wielkiego Elektora. W lipcu 1680 r. wśród ponad 800 obiektów skarbca, jaki pozostawił jej zmarły w 1669 r. ojciec Bogusław, zarządca Prus Książęcych z ramienia elektora, spisano 8 srebrnych kompletów miednic z nalewkami, w tym 4 pozłacane. Jedna z miednic ,z nalewką wielką, cale złocistą” była umieszczona „,w osobliwym puzdrze". Oprócz wspomnianych kompletów w rejestrze odnotowano jeszcze nalewkę z perłowej macicy, ze srebrną złoconą nakrywką ${ }^{40}$.

O nalewkach należących do magnaterii koronnej dowiadujemy się z testamentów, rejestrów wypraw ślubnych lub korespondencji. Marszałek wielki koronny Andrzej Opaliński w testamencie z roku 1592 zdecydował: ,ze srebra niech sobie żona moja weźmie nalewkę z miednicą, którą zechce"; do tego dodał kilka innych sreber (świeczniki, łyżki) ${ }^{41}$. Z kolei Krzysztof Opaliński, wojewoda poznański, miał kłopot z wykonawcą zamówionej nalewki. Żalił się bratu Łukaszowi, na Szwarca, złotnika poznańskiego, że ten „Zrobił jakąś machinę srogą, miednicę ze dzbanem i srebra w nię nagmazdał, z którego mogły być lichtarzyki i insze rzeczy do pokoju. Słałem, abym to mógł widzieć, nigdy mi do tego przyjść nie mogło"42. Wobec niesolidności złotnika, magnat czuł się bezsilny.

Nalewki odnotowują też źródła z drugiej połowy XVII w. Należały do najcenniejszych sreber, jakie rozdysponował w testamencie (z 1685 r.) inny magnat wielkopolski, posiadacz ośmiu kluczy dóbr, podstoli koronny, Stefan Adam Grudziński. Listę sreber otwiera dar dla sanktuarium w Częstochowie: „Miednica wielka złocista [...] do niej nalewka z koniem wielka pstro złocista”. Miednicę drugą, również pozłacaną, wykonaną w Augsburgu, do której „,nalewki nie masz" przekazuje żonie. Z kolei parze królewskiej zapisuje: miednicę z białego srebra „roboty auszpurskiej” wraz z nalewką „,do niej wielką z koniem i kawalerem na wierzchu”43. Zapewne były to dzieła sztuki złotniczej, bliskie poziomem wspominanym powyżej, zachowanym w zbiorach Kremla.

Śladów po nalewkach nie brak też z Małopolski. Nalewka srebrna i na miednicę ,srebro łamane" zostały wymienione w akcie divisio bonorum z 1597 r. wśród ruchomości Małgorzaty z Tarłów Oleśnickej, kasztelanowej małogoskiej ${ }^{44}$. Z kolei w rejestrze wyprawy ślubnej Katarzyny Lubomirskiej (córki Sebastiana żupnika krakowskiego) wychodzącej w tym samym 1597 r. za kasztelana krakowskiego, Janusza Ostrogskiego, obok luksusowych szat i klejnotów znalazły się również „nalewka i miednica srebrna”45.

Nalewki ceniła także elita szlachty pomorskiej. Znalazły się np. wśród precjozów zapisanych Annie, córce Dymitra Wejhera, kasztelana gdańskiego żonatego z Katarzyną z Bnina Opalińską (1628). Familia Wejherów rosła wówczas w siłę, wchodząc w krąg magnaterii nie tylko Prus Królewskich, ale także w skali całej Rzeczypospolitej. Anna oprócz gotówki i biżuterii otrzymała srebra, w tym: „Miednicę półzłocistą z nalewką jelonkiem” oraz dwie dalsze miednice, także półzłociste ${ }^{46}$.

Nalewki pozostawiały też ślad w księgach sądowych, np. wówczas, gdy padały łupem złodziei. W roku 1560 miednicę srebrną skradziono Janowi Bonerowi, wielkorządcy krakowskiemu, kasztelanowi chełmskiemu — zdobycz porąbana na sztuki została sprzedana Żydo-

\footnotetext{
40 Życiński S. 1989, s. 289.

41 Niemcewicz J.U. 1840, s. 370.

42 List z 9 sierpnia 1641 r., Listy. 1957, s. 13.

43 Testamenty 1681-1700. 2015, nr 64, s. 163.

44 Pielas J. 2004, s. 314.

45 Jankowski R. 2013, s. 220.

46 Testamenty. 2013, s. 142.
} 
wi $^{47}$. W 1590 r. dzbanek srebrny o pojemności kwarty oraz nalewkę cynową utracił Litwin, podczaszy nadworny, Andrzej Sapieha. Z jego kwatery ukradła je krakowska „dziewka przekupna”. Łup zastawiła u pewnej Żydówki ${ }^{48}$.

Na tle informacji o nalewkach magnatów czeskich i polskich, nie imponuje stan posiadania należącego do szlacheckiej elity Brandenburgii, Jerzego Krzysztofa von Goltza. Z nominacji elektora Fryderyka Wilhelma był on w latach 1646-1662 nadkomisarzem Nowej Marchii. Majątek własny (dwa dwory, wsie i miasteczko w okolicy Choszczna) szacował sam po odliczeniu zobowiązań na ok. 16000 talarów reńskich. W testamencie z 1648 r. drobiazgowo dzieli biżuterię i srebra między żonę, dwóch synów i cztery córki. Poza tym przeznaczył 200 łutów srebra (co najwyżej 350 g) na wykonanie miednicy i nalewki. Ten zestaw miał stanowić wspólną własność synów, w miarę potrzeby użytkowaną przez każdego z nich. Mógł być także pożyczany na przyjęcia córkom. Jak widać, jedna nalewka z miednicą miała obsłużyć wszelkie uroczyste biesiady (bankiety) w rodzinie brandenburskiego „magnata”49. Najpewniej przy stołach takich „ubogich magnatów”, a także w trakcie mniej uroczystych posiłków tych najzamożniejszych, nalewkę srebrną, podobnie jak srebra stołowe, zastępowała cyna. W inwentarzach największych rezydencji panów czeskich, oprócz kilku nalewek srebrnych odnotowywano od kilkunastu do ok. dwudziestu cynowych ${ }^{50}$.

Nalewka służyła też średniej szlachcie, zwłaszcza tej zamożniejszej, aspirującej do arystokracji, oraz magnaterii. Jan Vostrovec, zamożny członek czeskiego stanu rycerskiego (cztery dobra ziemskie), stracił majątek po klęsce protestantów. Według spisu skonfiskowanych mu ruchomości (z 1634 r.), wśród klejnotów i sreber posiadał dwie miednice z nalewkami ${ }^{51}$.

Nalewek nie brakowało też u szlachty koronnej i litewskiej. Były częścią wypraw ślubnych córek, zarówno magnackich, jak i średnioszlacheckich. Znajduje to potwierdzenie w rejestrach z XVII, a także z XVIII stulecia ${ }^{52}$. Więcej danych na ich temat zawierają jednak testamenty. Samuel z Mielęcina Mielęcki, dwuwioskowy posesjonat z ziemi wschowskiej, ale zarazem dworzanin królewski, w inwentarzu załączonym do testamentu z 1646 r., na pierwszym miejscu wśród sreber stołowych wymienia najcenniejszą „,miednicę z nalewką szrebrną złocistą tribowaną robotą grzywien 23. Skojcy 7, facit florenum 736, grzywna każda po złotych 32". Zestaw ten wartością przewyższał większość posiadanych przez Samuela klejnotów ${ }^{53}$. Z kolei Jan Noskowski, jednowioskowy(?) posesjonat z woj. kaliskiego, testamentem z 1652 r. przekazał franciszkanom w Pyzdrach (w ich kościele chciał być pochowany) dwa srebrne komplety — nalewki z miednicą ${ }^{54}$. Zmarła na przełomie lat 1660 i 1661 Zofia ze Smoszowskich Pogorzelska, posesjonatka z powiatu kcyńskiego, kasztelanówna santocka (ojciec Jan), po drugim zaś mężu kasztelanowa rogozińska, później kaliska, wspomniała w testamencie o srebrach zastawionych u różnych osób, w tym o „miednicy srebrnej pozłocistej [...] bez przykrycia z nalewką" ${ }^{55}$. Z kolei Władysław Strykowski (zm. w 1669 r.), właściciel dwóch wsi w powiatach kościańskim i poznańskim, w młodości dworzanin Władysława IV, w chwili śmierci stolnik poznański, w testamencie z roku 1668 precyzyjnie rozdysponował klejnoty i srebra. Z tych ostatnich „miednicę większą srebrną z nalewką większą miejscami złocistą” dla siostrzeńca, Konstantego

${ }^{47}$ Księga. 2013, s. 131.

${ }^{48}$ Księga. 2016, s. 82-83.

49 Brzustowicz G. 2007, s. 152, 163-164; Schwarz P. 1902, s. 294.

${ }^{50}$ Dějiny. 1995, s. 267-271.

${ }^{51}$ Bilek T. 1882 , s. 895.

52 Zielińska T. 1992, s. 297-300.

${ }^{53}$ Róża złota wysadzana rubinami -1000 zł, łańcuch złoty -654 zł, pozostałe już tańsze, Testamenty. 1631-1655. 2008, nr 53.

54 Tamże, $\mathrm{nr} 87$.

${ }^{55}$ Klint P. 2001, s. 127. 
Tomickiego. Drugi siostrzeniec, Mateusz, otrzymał wśród innych sreber „mniejszą miednicę z nalewką srebrną" 56 .

Nalewka srebrna „miejscami złocista” wartości 400 zł znalazła się wśród precjozów Katarzyny Radowickiej z solidnej wielkopolskiej familii Bojanowskich, wymienionych w testamencie z 1685 r. ${ }^{57}$ Miednicę srebrną z nalewką ze srebra „,bardzo przedniego”, o szacunkowej wartości ok. 500 zł, zapisał w roku 1686 bernardynom z Koła trójwioskowy szlachcic spod Turka w Sieradzkiem, Marcin Wysocki ${ }^{58}$.

Wreszcie przykład z Litwy. Piotr Kochlewski (zm. w 1646 r.), wywodzący się z ziemi wieluńskiej, posesjonat w woj. brzeskim (10 wsi), kalwin, od młodości związany z Radziwiłłami birżańskimi (dworzanin, klient?, agent, przyjaciel), w testamencie poprosił żonę, aby najstarszemu z trzech synów oddała „nalewkę z miednicą srebrną”; młodsi mieli dostać konwie i inne naczynia ${ }^{59}$.

Nalewki srebrne, a tym bardziej pozłacane, były bardzo kosztowne, stąd nie dziwi ich nieobecność w domach mniej zamożnych. Wszystko wskazuje, że tam były zastępowane naczyniami z cyny. W inwentarzu skromnego posesjonata $\mathrm{z}$ województwa kaliskiego, Piotra Niniewskiego (z 1641 r.), nalewki nie ma wśród wyrobów złotych i srebrnych, jest natomiast odnotowana wraz z miednicą wśród cyny ${ }^{60}$. Taki cynowy zestaw posiadała też wdowa po dzierżawcy z poznańskiego, Jadwiga z Belińskich Gorzyńska ${ }^{61}$. O dwóch miednicach z nalewkami wspominał w testamencie z roku 1682 Jan Małachowski, jednowioskowy szlachcic z woj. poznańskiego ${ }^{62}$. W tym samym roku cynową nalewkę z miednicą zapisał bratanicy Wojciech Bartoszewski, cząstkowy posesor dwóch wiosek ${ }^{63}$. Taki sam zestaw podarował synowi Franciszkowi, plebanowi we Wróblewie w woj. sieradzkim Piotr Kobierzycki, właściciel jednej wioski w Kaliskiem ${ }^{64}$. Posesor dwóch wiosek na Kujawach, podczaszy inowrocławski Aleksander Zakrzewski, oprócz niezbyt licznych sreber (nie było wśród nich nalewki), w testamencie z roku 1692 rozdysponował cynę: 11 półmisków, 12 talerzy, jedną misę oraz „miednicę napsowaną z nalewką po pierwsze(y) małżonce mojej" ${ }^{65}$. Wydaje się, że od standardu stanu posiadania magnatów lub zamożnej, aspirującej do elity szlachty nie odbiegał też stan posiadania duchownych — różnych obrządków i pozycji w hierarchii. Do przedmiotów o największej wartości i najwyższym kunszcie wykonania należały te posiadane przez hierarchów. Do Franciszka Potkańskiego, sufragana krakowskiego (1753-1786), należała np. miednica z nalewką. W dziewiętnastowiecznym opisie została określona jako „starożytna”, srebrna, pozłacana. Miednicę zdobiły „wybijane” postaci symbolizujące kraje: Francję, Niemcy, Hiszpanię i Włochy oraz cztery nauki: retorykę, dialektykę, geometrię i arytmetykę. Centrum „lustra” miednicy wypełniały postać anioła i trupia głowa. Nalewkę zdobiły personifikacje czterech żywiołów ${ }^{66}$. W testamencie (z 1625 r.) ubogiego unickiego biskupa chełmskiego i bełskiego, Atanazego Pokasty, wśród ok. 10 naczyń srebrnych rozdysponowano także miednicę z nalewką; choć srebrna, zapewne nie wyróżniała się ceną bądź formą artystyczną ${ }^{67}$.

56 Neumann P. 2004, s. 116.

57 Testamenty 1681-1700. 2015, s. 168 .

58 Tamże, s. 171.

59 Trawicka Z. 1975, s. 191.

60 Testamenty 1631-1655. 2008, nr 42.

${ }_{61}$ Tamże, nr 57 (testament z 1647 r.).

62 Testamenty 1681-1700. 2015, nr 27.

63 Tamże, nr 31.

64 Tamże, nr 68 (testament z 1686 r.).

65 Tamże, nr 131.

${ }^{66}$ Mączyński J. 1845, s. 148.

${ }^{67}$ Zielecka-Mikołajczyk W. 2012, s. 264. 
Dane testamentów i pośmiertnych inwentarzy o mieniu duchownych katolickich niższej i średniej rangi (od wikarego do kanonika) z Korony z wieków XVII-XVIII przeanalizował D. Główka. W ponad 300 przekazach odnotowano 6 srebrnych kompletów nalewek z miednicą; dwa z nich, pozłacane, należały do kanoników. Np. dziekan łucki a zarazem pleban w Kodniu Mikołaj Siestrzewitowski posiadał w roku 1682 miednicę z nalewką ,pozłocistą auszpurskiej roboty"68. Inni poprzestawali zapewne na nalewkach cynowych (8 kompletów z misą). Bartłomiej Lisowic, pleban w wielkopolskim Buku (1625 r.) miał dwa zestawy — cynowy i miedziany ${ }^{69}$.

Posiadaczy srebrnych nalewek nie brakowało też wśród mieszczaństwa, przede wszystkim wśród elity. Świadczą o tym przykłady choćby z Krakowa. Rajca krakowski Krzysztof Szober zapisał (w 1633 r.) synowi Stanisławowi „nalewkę z miednicą srebrną ${ }^{70}$. Dwadzieścia lat później (w 1653 r.) Teresa Pipanowa, żona rajcy, przekazała córce Magdalenie „,nalewkę srebrną szczerozłocistą z herbem ojca"71. W 1677 r. kolejny rajca, Jan Pyrnus, zapisał synowcowi nalewkę $\mathrm{z}$ miednicą srebrną ${ }^{72}$.

Analiza przedstawionego powyżej, zróżnicowanego materiału skłania do następujących wniosków. Tytułowa nalewka, wykonana z metali szlachetnych, czasami też z drogich kamieni, bursztynu, muszli, była częścią zestawu (dzban — miednica) używanego przy ceremonialnym myciu dłoni. Publiczne mycie rąk przed oficjalnym posiłkiem nie było jedynym zastosowaniem nalewki. Stanowiła także część wyposażenia prywatnej gotowalni, gdzie dokonywano codziennej toalety (obmycie rąk, twarzy). Do takich „toaletowych" nalewek z miedniczkami należały: jedyna opisana precyzyjnie w analizowanych źródłach jako część zestawu toaletowego (wraz z lustrem, puderniczkami i innymi utensyliami) zapisana żonie przez elektora brandenburskiego, Fryderyka III (1692); być może także nalewka należąca do królowej Konstancji, żony Zygmunta II Wazy (1611) oraz kolejna, eksponowana w latach osiemdziesiątych XVII w. w pałacu elektorów Saksonii w Dreźnie. Rozróżnienie funkcji poszczególnych nalewek, z reguły nie jest do końca pewne, jako że autorów większości informacji źródłowych interesowały nie owe funkcje, lecz przede wszystkim wartość materialna (w wadze kruszcu, w pieniądzu), w drugim zaś rzędzie estetyka, względnie walory artystyczne przedmiotu.

Społeczny krąg posiadaczy nalewek był dość szeroki. Były atrybutem dworów monarszych — od Madrytu po Moskwę, Wiednia i Warszawy nie pomijając. Były typowym wyposażeniem siedzib elektorów i pomniejszych władców niemieckich. Nie brakowało ich w salach jadalnych arystokracji i magnaterii (Czechy, kraje niemieckie, Rzeczpospolita). Posiadała je także średnio zamożna szlachta (czeska, polska). W przypadku tej ostatniej ich właścicielami byli ludzie o aspiracjach powyżej średniej — przy skromnym majątku szukający awansu poprzez służbę na dworze królewskim, koligacje senatorskie itp. Wreszcie nalewek srebrnych nie brakowało także w jadalniach duchowieństwa (zarówno hierarchów, jak średniej i niższej rangi) oraz miejskich patrycjuszy.

Jako precjoza, często też dzieła sztuki mistrzów z renomowanych ośrodków rzemiosła (Augsburg, Norymberga, Antwerpia, Gdańsk), pełniły nalewki rolę nie tylko użytkową. Wartością dorównywały, a niekiedy przewyższały przechowywane w skarbcach inne srebra lub klejnoty; tezauryzowane współtworzyły materialne podstawy potęgi rodu. Pozyskiwano je drogą zamówień i zakupów, dziedziczono, otrzymywano w darze od poddanych, krewnych, przyjaciół,

${ }^{68}$ Główka D. 2004, s. 179.

${ }^{69}$ Tamże, s. 179.

70 Dług. 2011, s. 13.

71 Tamże, s. 35.

72 Tamże, s. 49. 
choćby z okazji uroczystości rodzinnych. Testamentalnie przekazywane były rodzinie, ale także instytucjom kościelnym (zapisy pobożne), przyjaciołom, władcom. Często pełniły rolę darów dyplomatycznych — z okazji poselstw, traktatów, zaślubin, chrzcin. Konkretnie wyceniane, mogły zawsze powrócić do obiegu, być sprzedane, podarowane. Bywały przedmiotem zastawu, kradzieży, rabunku i konfiskat. Przykładem najlepszym wielka liczba sreber, w tym nalewek, zgromadzona w czasie wojny trzydziestoletniej przez Albrechta Wallensteina. W czasach spokojnych stanowiły, obok innych sreber stołowych, jeden z chętniej publicznie prezentowanych elementów majątku. W ten sposób podnosiły prestiż władcy — magnata — szlachcica.

Nawet ścisła elita nie zawsze sięgała po zastawę najcenniejszą. W dni powszednie, podczas nieobecności znamienitych gości, przy niższych stołach, pojawiały się w jadalni nalewki $\mathrm{z}$ miednicami cynowymi, w zasobach dworu $\mathrm{z}$ reguły dużo liczniejsze niż te srebrne. $\mathrm{Z}$ kolei w siedzibach ubogiej szlachty cyna herbowa po prostu zastępowała herbowe srebra, w tym również nalewkę.

Przedstawiony powyżej obraz to wstępny szkic, w wielu fragmentach wymagający poszerzenia i pogłębienia. Pokazuje jednak możliwości badawcze, jakie daje całościowe spojrzenie na rolę dwóch przedmiotów, w komplecie stanowiących istotny element kultury materialnej europejskich elit doby nowożytnej. Element dotychczas traktowany marginalnie, a zarazem fragmentarycznie i jednostronnie.

Adres Autora:

prof. dr hab. Andrzej Klonder

Instytut Archeologii i Etnologii PAN

al. Solidarności 105

00-140 Warszawa

andrzej.klonder@gmail.com

ORCID: 0000-0002-7542-0929

\section{BIBLIOGRAFIA}

\section{Źródła i opracowania publikowane}

Bilek Tomaš. 1882. Déjiny konfiskaci v Čechach po r.1618, v Praze.

Der Briefwechsel. 1984. Der Briefwechsel zwischen Philipp Hainhoferund Herzog August d.J. von Braunschweig - Lüneburg, wyd. R. Gobiet, München.

Brzustowicz Grzegorz Jacek. 2007. Ostatnia wola pana na Korytowie Jerzego Krzysztofa von der Goltza. Przyczynek do kultury szlachty nowomarchijskiej w XVII wieku, „Przegląd Zachodniopomorski”, t. XXI, s. 151-164.

Bůžek Václav, Hrdlička Josef. 1998. Rodinnýživot poślednich pánů z Hradce ve světle jejich korespondence, Opera Historica 6, České Budějovce, s. 145-271.

Corvinus. 1739. Frauenzimmer-Lexicon. Nutzbares, galantes und curioses, Leipzig.

Dějiny. 1995. Dějiny hmotné kultury, t. II (1), red. J. Petrán i in., Praha.

Dług. 2011. Dlug śmiertelności wypłacić trzeba. Wybór testamentów mieszczan krakowskich z XVIIXVIII wieku, oprac. E. Danowska, Kraków.

Elias Norbert. 2011. O procesie cywilizacji, Warszawa.

Gdański inwentarz. 1984. Gdański inwentarz mienia domowego Magdaleny Szumanowej z 1706 roku, wyd. A.R. Chodyński i in., Wrocław.

Główka Dariusz. 2004. Majątek osobisty duchowieństwa katolickiego w Koronie w XVII i XVIII wieku, Warszawa.

Hainhofer. 1834. Philippe Hainhofers Reise-Tagebuch, Stettin. 
Historia. 1978. Historia kultury materialnej Polski, t. III: Od XVI do polowy XVII w., red. A. Keckowa i in., Wrocław.

Jankowski Rafał. 2013. Spis wyprawy Katarzyny Lubomirskiej z 1597 roku, „Miscellanea Historico-Archivistica", t. XX, s. 213-222.

Klint Paweł. 2001. Testament Zofii ze Smuszewskich Pogorzelskiej, „Genealogia. Studia i materiały historyczne", t. 13, s. 117-128.

Knackfuß Hermann. 1888. Deutsche Kunstgeschichte, Bd 2, Bielefeldt.

Kodzik Joanna. 2014. Ceremoniat w Rzeczypospolitej i Francji, [w:] Rzeczpospolita w oczach cudzoziemców z Francji i Niemiec, red. A. Mikołajewska i in. Warszawa, s. 167-187.

Kopaliński Władysław. 1985. Stownik mitów i tradycji kultury, Warszawa.

Kossowicz Jan Michał. 2017. Diariusz podróży po Europie (1682-1688), wyd. A. Markiewicz, Warszawa.

Král Pavel. 2002. Mezi životem a smrtí, České Budéjovice.

Księga. 2013. Księga kryminalna miasta Krakowa 1554-1625, wyd. W. Uruszczak i in., Kraków.

Księga. 2016. Księga kryminalna miasta Krakowa 1589-1604, wyd. W. Uruszczak, Kraków.

Kunstgewerbemuseum. 1983. Kunstgewerbemuseum Berlin, Berlin.

Leitsch Walter. 2009. Das Leben am Hof König Sigismunds III von Polen, Wien.

Lemberg Margaret. 1994. Im Strudel der Böhmischen Ständekatastrophe. Die unvollendete verlöbniss des Albrecht Johann Smiřicky mit Amelie Elisabeth von Hanau und der Kampf um die Erbe, Bohemia 35, s. 1-44.

Listy. 1957. Listy Krzysztofa Opalińskiego do brata Eukasza z lat 1641-1653, wyd. R. Pollak, Wrocław.

Łoziński Władysław. 2006. Życie polskie w dawnych wiekach, I wyd., Lwów 1907, Warszawa.

Manikowski Adam. 1991. Toskańskie przedsiębiorstwo arystokratyczne w XVII wieku. Społeczeństwo elitarnej konsumpcji, Warszawa.

Mączyński Józef. 1845. Pamiątka z Krakowa. Opis tego miasta i jego okolic, cz. 3, Kraków.

Neumann Piotr. 2004. Testament Władysława Strykowskiego stolnika poznańskiego z 1668 r., „Genealogia”, t. 16, s. 105-117.

Niemcewicz Jan Ursyn. 1840. Zbiór pamiętników historycznych o dawnej Polsce, t. 5, Lipsk.

Pielas Jacek. 2004. Majątek ziemski i ruchomy zamożnej szlachcianki w końcu XVI wieku. Przyczynek do dziejów wygasłej linii Tartów herbu Topór, „Między Wisłą a Pilicą”, t. 5, s. 307-315.

Pielas Jacek. 2013. Podziały majątkowe szlachty koronnej w XVII wieku, Kielce.

Volckmar Nicolaus 2005. Viertzig Dialogi 1612, źródło do badań nad życiem codziennym w dawnym Gdańsku, wyd. E. Kizik, Gdańsk.

Rezidence. 1999. Rezidence a dvory v ranem novověku, Opera Historica, 7, red. V. Bůžek i in., České Budějovice.

Rohr von Julius Bernhard. 1733. Ceremoniel Wissenschaft der Grossen Herren, Berlin.

Rottermund Andrzej. 1987. Dworski stół paradny - sztuka i ceremoniat (zarys problematyki), „Materiały Muzeum Wnętrz Zabytkowych w Pszczynie”, t. 4, s. 37-72.

Schwartz Paul. 1902. Die Neumark während des dreißigjährigen Kriegs, Theil II, Landsberg.

Skarby. 1998. Skarby Kremla. Dary Rzeczypospolitej Obojga Narodów, red. N.W. Raszkowan i in., Warszawa.

Słownik polszczyzny. 1979. Słownik polszczyzny XVI wieku, t. 14, Wrocław.

Słownik staropolski. 1965. Stownik staropolski, t. 5, Wrocław.

Śliż Natalia. 2007. Testament Piotra Kochlewskiego sędziego ziemskiego brzeskiego z 1646 roku, „Zapiski Historyczne”, t. 72, s. 91-103.

Testamenty 1631-1655. 2008. Testamenty szlacheckie z ksiag grodzkich wielkopolskich z lat 1631-1655 , wyd. P. Klint, Poznań. 
Testamenty 1681-1700. 2015. Testamenty szlacheckie z ksiag grodzkich wielkopolskich z lat 1681-1700 , wyd. P. Klint, Wrocław.

Testamenty. 2013. Testamenty szlachty Prus Królewskich z XVII wieku, wyd. J. Kowalkowski i in., Warszawa.

Testamenty Zygmunta III. 2013. Testamenty Zygmunta III Wazy, wyd. W. Kaczorowski, Opole.

Die Testamente. 1915. Die Testamente der Kurfürsten von Brandenburg, wyd. H. Caemmerer, München.

Taźbierski Zdzisław. 1986. Ceremoniał dworsko-dyplomatyczny w praktyce negocjacyjnej Polski z Anglia w XVI-XVIII wieku, Olsztyn.

Trawicka Zofia 1975. Memoriat Piotra Kochlewskiego, „Odrodzenie i reformacja w Polsce”, t. 20, s. $185-199$.

Wasilewicz Marek. 2016. Początki polskiej «haute cuisine» — jak jadano przy królewskim stole Jagiellonów, [w:] Wiktuaty, kuchnia, kultura. Jedzenie w perspektywie historycznej, red. P. Jędrzejewski i in., Kraków, s. 129-138.

Wiśniewska Halina, Tymiakin Leszek. 2010. Kunszt pisania po polsku w królewskim Przemyślu w XVI-XVIII w. Przemyśl.

Zielecka-Mikołajczyk Wioletta. 2012. Prawosławni i unici w Rzeczypospolitej XVI-XVIII wieku wobec życia i śmierci w świetle testamentów, Warszawa.

Zielińska Teresa, 1992. Kosztowności jako sktadnik wyposażenia kobiet w XVII i XVIII w., [w:] Miasto - Region - Spoleczeństwo, red. E. Dubas-Urwanowicz i in., Białystok, s. 295-305.

Życiński Stanisław. 1989. Złotnictwo w skarbcu królewieckim Ludwiki Karoliny Radziwiltówny z roku 1680, „Przegląd Zachodniopomorski”, t. 23, s. 277-301.

\section{A SILVER JUG WITH A BOWL - AN ATTRIBUTE OF THE ELITE CULTURE OF THE TABLE IN EARLY-MODERN CENTRAL EUROPE. INTRODUCTORY REMARKS}

Ceremonial handwashing was an important introduction to formal public meals of social elites (feasts, banquets). This tradition, going back to antiquity and cultivated in the Middle Ages, was continued in the early-modern period. The handwashing was performed using a jug and a bowl.

Information about such sets is scattered in various types of sources; there are examples surviving in museums, iconography and mentions in written sources from the $16^{\text {th }}-18^{\text {th }} \mathrm{c}$. The last type includes inventories, testaments, letters, travel accounts, encyclopedias, treatises on court ceremonial, manuals, handbooks, and documents concerning purchases, donations, confiscations and thefts.

Jugs made of noble metals, gemstones, pearls and other luxurious, often exotic materials were very precious, also due to their aesthetic value. They were produced by goldsmiths from France, the Netherlands, leading German centres of this craft (Augsburg, Nürnberg) and local centres (e.g. Gdańsk, Poznań).

Those luxurious vessels were used at royal courts all over Europe from the Iberian Peninsula to Moscow, including the Habsburg court in Vienna and the Vasa court in Warsaw. They were also found at the courts of electors and lesser rulers of the Reich. As to aristocracy (magnates), the author focuses on examples from Poland and Bohemia, finding a confirmation that such artefacts were widely used in residences of the elite. The same applied to middle nobility, but in this group silver handwashing jugs were usually bought by those that aspired to social advancement, e.g. the king's courtiers or people marrying into senatorial families. Such jugs 
were also owned by Catholic clergy (from parish priests to bishops) and by burgher patricians (for example in Cracow).

As to the functions of jug-and-basin sets, smaller ones were used not only for public handwashing, but also, as indicated by several mentions, for everyday toilet in private. They were also treated as an investment; they were kept in treasuries, counting among the most expensive valuables. Before feasts, gests could admire them among other silverware exhibited on special tables or shelves. They were also used for decorating grand rooms of residences (e.g. the Silberbufett in the Berlin Castle) to enhance the prestige of the family. Being precious and at the same time easy to transport, they also served in policy-making as gifts brought by envoys to foreign rulers and other influential personages. The same applied to domestic politics. They were also bequeathed in last wills to relatives, friends, patrons and clients, or to help the salvation of the soul, to Church institutions.

Sometimes noble metal vessels were replaced by tin ones. Even the richest families used tin tableware on weekdays, including handwashing jugs and bowls, instead of silverware. The supply of tin was much larger than that of silver. In the households of petty nobility silverware could not be afforded and there were only tin vessels, including jugs and bowls.

Translated by Izabela Szymańska 
